\title{
Race, Charter Schools, and Conscious Capitalism: On the Spatial Politics of Whiteness as Property (and the Unconscionable Assault on Black New Orleans)
}

\author{
KRISTEN L. BURAS \\ Georgia State University
}

In this article, Kristen L. Buras examines educational policy formation in New Orleans and the racial, economic, and spatial dynamics shaping the city's reconstruction since 2005. More specifically, Buras draws on the critical theories of whiteness as property, accumulation by dispossession, and urban space economy to describe the strategic assault on black communities by education entrepreneurs. Based on data collected from an array of stakeholders on the ground, she argues that policy actors at the federal, state, and local levels have contributed to a process of privatization and an inequitable racial-spatial redistribution of resources while acting under the banner of "conscious capitalism." She challenges the market-based reforms currently offered as a panacea for education in New Orleans, particularly charter schools, and instead offers principles of educational reform rooted in a more democratic and critically conscious tradition.

New Orleans has become the premier experimental site for urban educational reform in the United States. There is no other city with a higher proportion of charter schools or a more comprehensive program of alternative teacher recruitment. Veteran teachers were fired en masse in 2006, and today the city's schools are headed toward complete charterization. Based on five years of qualitative research, including document analysis and interviews with a broad range of stakeholders and organizations, this article reveals a strategic and racially exclusive pattern of educational policy making at the fed-

Harvard Educational Review $\quad$ Vol. $81 \quad$ No. 2 Summer 2011

Copyright (C) by the President and Fellows of Harvard College 
eral, state, and local levels. Drawing on critical theories of race, political economy, and space to analyze the policy ecology surrounding reforms, I argue that New Orleans charter schools are less about responding to the needs of racially oppressed communities and more about the Reconstruction of a newly governed South-one in which white entrepreneurs (and black allies) capitalize on black schools and neighborhoods by obtaining public monies to build and manage charter schools. ${ }^{1}$ Although market-based educational reforms in New Orleans are presented by policy makers as innovative and democratic, they are nonetheless premised on the criminal dispossession of black workingclass communities and the teachers and students who have contributed to the city's culture and history. Lawmakers and entrepreneurs frame these reforms as a socially conscious effort to advance equity and improve public schools, rather than allowing the traditional profit motive to define their efforts-what has been referred to as conscious capitalism. In reality, however, the city's urban space economy is reshaped along racial lines, exacerbating inequity and deepening the confluence of capital accumulation, property rights, and whiteness.

In this article, I critically examine the relationships among policy-making processes, spatial form, and power as they pertain to schooling and the racialeconomic reconstruction of urban space in New Orleans. To this end, I present a reading of New Orleans through various "spatial frames" (Harvey, 2006; Lefebvre, 1974). By drawing on such frames, moving across them, and learning from their dialectical tensions, I render a more complete and layered understanding of the racialized urban space economy of New Orleans, its political dynamics, and the politics of dispossession. The pressing questions are: How is the urban space economy of New Orleans produced? What is its relationship to capital accumulation and racial formation? And in what ways does whiteness function as a form of property, endowing its possessors with the rights to use, appropriate, and benefit from the city's assets while dispossessing or excluding communities of color from the same entitlements?

In responding to these questions, I document and critically analyze the policy ecology - the complex and interconnected set of relationships influencing the shape of educational reform in New Orleans-and the city's corresponding urban space economy. This includes the role of federal and state governments in zoning southern space as an experimental site for charter school reform and alternative teacher recruitment; the role of local government, particularly the Bring New Orleans Back Commission (BNOB), in envisioning a racially inspired, market-based plan for reconstruction of the city and its schools; the role of nonstate policy actors, such as Tulane University's Cowen Institute for Public Education Initiatives, New Schools for New Orleans (NSNO; charter school incubator), and teachNOLA (an alternative teacher recruitment initiative), in advancing the takeover and privatization of New Orleans Public Schools (NOPS) by education entrepreneurs; and the role of the Recovery School District (RSD) and School Facilities Master Plan (SFMP) in establishing the blueprint for which schools would be rebuilt and where, 
as well as the uneven urban space economy produced as a result. I discuss the effects of these actors and organizations on working-class communities of color, including black veteran teachers and students, and conclude with the implications of the school reform movement in New Orleans for urban educational justice. In so doing, I challenge the notion that charter schools and school choice are a panacea for race and class inequities and offer principles of educational reform rooted in a more democratic and critically conscious tradition of reconstruction.

\section{Methodology}

As a New Orleans native, I have been involved in educational activism in the city for the past two decades. Since 2005, I have conducted ongoing research focused on newly instituted educational reforms, particularly the political dynamics of policy formation and effects on working-class communities of color (see Buras 2005, 2007, 2009, 2011a, 2011b, 2011c, forthcoming; Buras, Randels, Salaam, \& Students at the Center, 2010). I travel to New Orleans at least once quarterly and generally stay for seven to ten days at a time, working with educational and community organizations; meeting with teachers, grassroots activists, and other stakeholders; and collecting relevant documents. I am committed to this work because of the rich and complex cultural history of New Orleans as well as my enduring belief that the South remains an understudied yet crucial context for understanding black education and the politics of racial and economic power. Current educational reforms in New Orleans, and the struggles surrounding them, provide an important window onto these issues and also illuminate the implications of market-based education reform nationally.

In this article, I focus on data related to the recent history of educational policy formation and implementation, particularly with respect to charter schools, and the racial, economic, and spatial dynamics shaping the reconstruction of New Orleans. The evidence used to inform the arguments in this article is taken from historical, documentary, interview, and participant observation data. (See appendix 1 for a list of selected data sources and methods of data collection organized by institution.)

I consulted primary and secondary historical sources, school district policies and documents, state data and reports, news articles from local and national sources, and organizations' literature, including their Web sites. With key documents, I performed several readings and made careful notations on content pertaining to race, political economy, past (pre-2005) and present (post-2005) educational assets and challenges, and perspectives on current school reform. In addition, I wrote informal memos and created sketches that charted confluent perspectives and linkages between policy actors at different geographic scales (local, state, and national), which required indexing and crossreferencing the content of documents. 
I have interviewed a broad range of more than fifty education stakeholders. I conducted semi-structured life-world interviews (Kvale, 1996), typically lasting one to two hours. I interviewed organizers affiliated with a range of parent, teacher, school, and community reform organizations, including representatives of the state and local teacher unions and veteran teachers. I identify these latter two sets of interviewees by referring to them as either "representatives" of one of the teacher unions or "affiliates" (that is, veteran teachers). ${ }^{2}$ I transcribed each interview and coded for recurrent themes, made notations on the patterns observed, and authored analytic memos. I also took field notes in multiple venues, such as public meetings and community spaces, and on informal, ongoing exchanges with stakeholders.

\section{New Orleans Public Schools: A Brief History}

For most of their history, public schools in New Orleans were not intended to support children of color or their black teachers but were instead considered the property of southern whites. The history of slavery, legalized segregation, ongoing racism, and white flight from the city has translated into strategic state neglect and disinvestment in African American education (Buras, 2007; DeVore \& Logsdon, 1991). Brown v. Board of Education in 1954 led to mass white flight from the city's public schools. Despite shifting racial demographics, NOPS did not have its first black superintendent until 1985, and from 1996 to 2005 the district had nine interim or permanent superintendents (DeVore \& Logsdon, 1991; UTNO, LFT, \& AFT, 2006). Throughout the 1990s, the district suffered ongoing financial crises.

The state takeover of Orleans Parish began in June 2005. At that time, the Louisiana Department of Education entered into a memorandum of understanding with Orleans Parish School Board (OPSB), which authorized the state to manage the district's $\$ 30$ million deficit. Interestingly, the state's financial management would be accomplished by contracting with Alvarez and Marsal, a private accounting firm. In turn, Alvarez and Marsal suggested that some of the district's operations, such as food service, payroll, and transportation, be privately contracted (Mirón, 2008). Thus, the grounds for public school decentralization and privatization had been laid through historic and racially targeted neglect, generating the educational crisis that conscious capitalists have allegedly stepped in to resolve (Buras, 2007, 2009; Saltman, 2007).

Despite these oppressive conditions, New Orleans developed one of the strongest black teacher unions in the nation, United Teachers of New Orleans (UTNO), with a long history of struggle for equal pay for black and white teachers and struggle for more adequate educational resources (Randels, 2010)..$^{3}$ A large portion of the city's black middle class was public school teachers. By 2005, veteran teachers in New Orleans had taught for decades in horrendously underfunded schools and had more than earned their pensions. For reformers, all of this needed to be fundamentally altered; state takeover 
of New Orleans public schools, combined with groundbreaking charter school reform, would provide the means for change. Hurricane Katrina provided the window of opportunity in August 2005: in the minds of reformers, damage or destruction to 80 percent of the city's public schools created an absolute space for calculated reconstruction and profit making.

Prior to August 2005, the locally elected OPSB controlled 128 public schools in the city of New Orleans. After August 2005, the state-run Recovery School District (RSD) assumed control of 107 of the city's public schools and chartered the majority of them, while only a handful of schools remained under local governance through OPSB. Thus, by 2009-2010, the majority of schools were charters (fifty-one of eighty-eight schools enrolling 61 percent of students), with more than thirty different providers in two different school districts (Cowen Institute, 2010) - the Recovery School District (RSD) in New Orleans governed by the state's Board of Elementary and Secondary Education (BESE) and New Orleans Public Schools (NOPS) governed by the Orleans Parish School Board (OPSB) (see figure 1). While a smaller number of traditional, state-run schools remained in each district, the operation of charter schools by education entrepreneurs took precedent. This would be the new model of educational reform in New Orleans, one that conscious capitalists claimed was in the best interest of still-displaced communities.

\section{The Portfolio Model of Education}

We did a different model [in New Orleans]. We decided to take the failing schools away from the school district ... And in doing that, the local policies go away, the collective bargaining agreement goes away ... So out comes the building, the students, and the money and a fresh start ... There are still people in the minority community angry that we took over the schools and that we disenfranchised them.

\section{Leslie Jacobs, charter school advocate and architect of Louisiana's Educational Assessment Program}

They came back and said, "Oh, you no longer have jobs. The district no longer exists. We're going to split it up, make some charters. The state's going to take control of everything." . . . I asked one state legislator, "How could you do that with us being displaced and still abide by open meetings law?" Because when you do stuff like that, you have to post notice. You have to invite the public. You have to get their input ... He said, "Well, what we did was we called up a few people that we knew was back in town and invited them over to my house, and we sat down and began to dismantle the district" ... This is the kind of underhanded tactics that was going on while our family members were still floating in the waters of Katrina, while our schoolchildren were still floating in that water.

Veteran public school teacher in New Orleans

Leslie Jacobs speaks with promise about the fresh start provided by a different educational model in New Orleans. As a former member of the OPSB and BESE and a member of the city's white business elite, she commands attention 
FIGURE 1 Public schools in New Orleans, 2009-2010

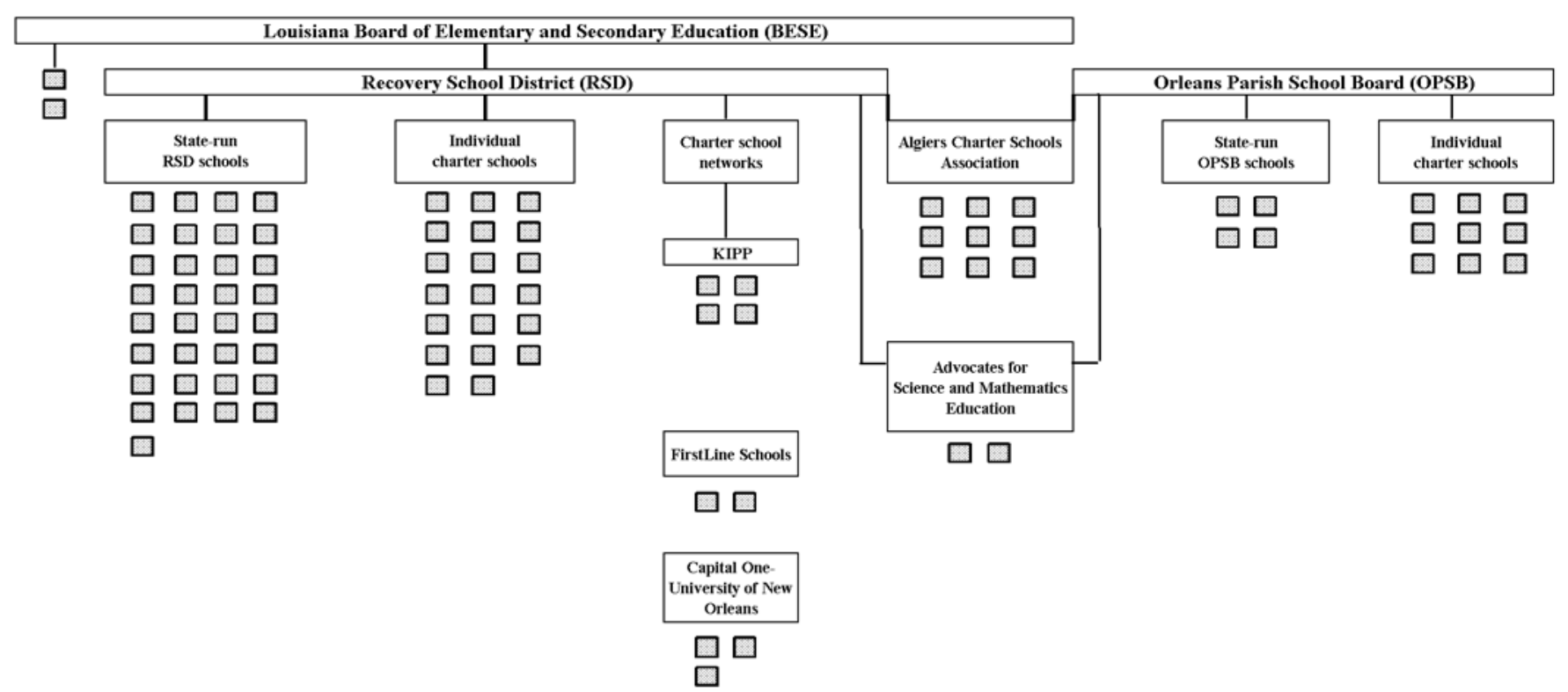

Sources: This figure was created using directories and reports from the Louisiana Department of Education, the Recovery School District, and the Orleans Parish School Board.

Note: Each gray rectangle represents a school.

Copyright $\odot$ Kristen L. Buras 
and is able to circulate a number of claims about what is best for the "minority community." Paul Hill, a nationally recognized conservative who leads the Center on Reinventing Public Education, echoes Jacobs. He writes with his colleagues:

[A] "portfolio school district" is . . . based on a simple set of ideas: a district that provides schools in many ways-including traditional direct operation, semiautonomous schools created by the district, and chartering or contracting to independent parties-but holds all schools . . . accountable for performance ... Many things traditional school districts were originally built to do . . . are at odds with operation of schools by diverse providers and replacing schools and staff that do not perform. Adopting a portfolio model means rebuilding a school district from the ground up ... Traditional educators, and citizens who do not want their schools to change, inevitably feel insulted and dispossessed. (Hill et al., 2009, pp. 1-2)

Much like Jacobs, Hill presents a "simple set of ideas" about how to improve urban school performance. Yet, as one black veteran public school teacher indicated, these so-called reforms are rapacious. Notably, they are not only rapacious in their effects; the process of implementing these reforms, far from being democratic, has been more akin to a deadly assault on black schools and neighborhoods.

Educational reformers such as Jacobs and Hill make some key assertions (Buras \& Apple, 2005; Saltman, 2010). First, they argue that a market-driven, competitive model of education is best. This portfolio model (invoking the language of business is not accidental) allegedly ensures high-performing and accountable schools, since low-performing schools run by inept "service providers" will fail to generate the allegiance of clients and ultimately will be removed. Second, they assert that doing away with local politics and bureaucracy (references to teacher unions are not accidental either) will lead to fresh and innovative practices. That is, freed from the shackles of regulatory government and labor protections, schools will be able to deliver a nonstandardized curriculum and to do so more efficiently and cost effectively. Third, they claim that knowledgeable consumers are able to equitably navigate the newly renovated system of schools based on access to performance data. Jacobs has made clear that in New Orleans "we are a system of schools versus a school system" and that "every single school is a school of choice" (Charter Revision Commission, 2010, pp. 10-11).

Hill and his colleagues (2009) stress that "there is only one way to judge a portfolio district" - namely, by its capacity to "create a process of continuous change under which ... the quality of schools available [and] the district's overall responsiveness to needs in the community . . . will steadily improve" (p. 47). Hill's words resonate with a newly emerging movement around social entrepreneurship and conscious capitalism. As one of the leading proponents indicates, conscious capitalists establish organizations to address specific problems and “reject Milton Friedman's argument that a corporation's primary 
responsibility is to its shareholders" (Miester, 2010, p. 17). Instead, all businesses "should have a purpose beyond profits . . . The more we can get entrepreneurs to step up and be conscious capitalists, the less we're going to need regulations" (p. 17). Education entrepreneurs assert that educational marketization and school choice advance equity and opportunity for communities long harmed by a state monopoly on public education. Is this the case? Is this the intent?

The experiences of families such as Michelle Mosby and her six-year-old granddaughter La-Aarea cast doubt on reformers' assertions. Mosby hoped to get La-Aarea into first grade at Akili Academy, a charter school in the Recovery School District (RSD), but learned several weeks before the end of summer that it was already too late. To complicate matters, Mosby, "who works the cash register in a cafeteria, does not have a flexible work schedule or well-placed contacts to help her navigate the complicated new landscape" (Carr, 2009, para. 7). Meanwhile, La-Aarea was attending a state-run school in the RSD, one that Mosby disliked because of its large classes, inadequate homework, and the seeming disengagement of her granddaughter, who never mentioned school. Like most parents and caregivers, Mosby sought "a good school close to where she lived and worked" (para. 25). She next tried Success Preparatory Academy, a brand new charter school in the RSD, but discovered a sign on its door that the first grade was full. She was invited to complete an application for the waiting list but was informed that applications were only accepted in the afternoon between one and four o'clock. During the first week of school, Mosby was still seeking a placement. Many schools were full or simply did not return her calls, and she could not afford to miss work to continue her search (Carr, 2009). There was no choice: La-Aarea would remain at the same school she attended the previous year, one of the state-run RSD schools considered to be a "dumping ground" for the children not selected by charter schools (UTNO et al., 2006).

\section{Argument and Theoretical Framework}

In this article, I question the notion of socially conscious capitalism and argue that what is happening in New Orleans is, instead, unconscionable and has little to do with improving school performance for children of color. Educational reforms in New Orleans are not designed to respond to oppressed communities or to enhance public school performance, even if they are often couched in such language. Rather, this is a feeding frenzy, a revivified Reconstruction-era blueprint for how to capitalize on public education and line the pockets of white entrepreneurs (and their black allies) who care less about working-class schoolchildren and their grandmothers and much more about obtaining public and private monies and an array of lucrative contracts.

Schools are performing just as reformers tacitly, if not explicitly, intend because the educational reform model is not about improving urban education. These reforms are a form of accumulation by dispossession, which David 
Harvey (2006) defines as a process in which assets previously belonging to one group are put in circulation as capital for another group. In New Orleans, this has included the appropriation and commodification of black children, black schools, and black communities for white exploitation and profit. As I show, this process is intimately connected to the production of an urban space economy (Harvey, 1973) premised on capital accumulation and the politics of white supremacy. Here again, Harvey conceives of the city as a built environment that embodies the conditions and spatial ordering necessary for capital accumulation to proceed. Since every economic-spatial project is also a racial one-a point inadequately addressed by Harvey's largely Marxist framework-I also rely on Cheryl Harris's (1995) critical race theory of whiteness as property. For Harris, white identity has historically enabled its possessors to use and enjoy a host of benefits and assets and to exclude communities of color from such entitlements. In New Orleans, white entrepreneurs have seized control of a key asset in black communities-public schools-and through state assistance, charter school reform, and plans for reconstruction, have built a profitable and exclusionary educational system that threatens to reinforce rather than challenge the political economy of New Orleans.

This economy has long been based on the economic exploitation of African Americans, particularly in the cultural tourism industry. Kalamu ya Salaam, a New Orleans poet and teacher, describes the interconnections between political economy, race, and schooling:

Education is ground zero in the systemic exploitation of black people in New Orleans-ground zero because public schools are the direct feeder for the necessary, albeit unskilled, labor needed for the tourist-oriented economy . . . In New Orleans they are building more hotels every day. Where will the bellhops and maids come from? ... Our schools are the way they are because the economy ... continues to require a labor force to clean, cook, and serve. (Buras et al., 2010, pp. 66-67)

Salaam's complex analysis resonates with the ecological framework I seek to elaborate on in this article (see also Lipman, 2004; Omi \& Winant, 1994; Tate, 2008). According to Marcus Weaver-Hightower (2008), policy ecology "consists of the policy itself along with all of the texts, histories, people, places, groups, traditions, economic and political conditions, institutions, and relationships that affect it or that it affects" (p. 155). This is what Harvey (2006) refers to as the socioecological web of life, or the critical analysis of space-time at a variety of geographical scales. Figure 2 presents a visual representation of the web of federal, state, and local actors that has shaped the racial-economic reconstruction of public schools in New Orleans over the past five years.

Before undertaking my analysis, I delineate the spatial frames I use to illuminate the perspectives of education actors. Absolute space is fixed, bounded, calculated, timeless, and presumed to have the precision of Cartesian geometry: a current grid of city streets, a map of school buildings. Relative space- 


\section{FIGURE 2 Policy ecology of New Orleans Public Schools}

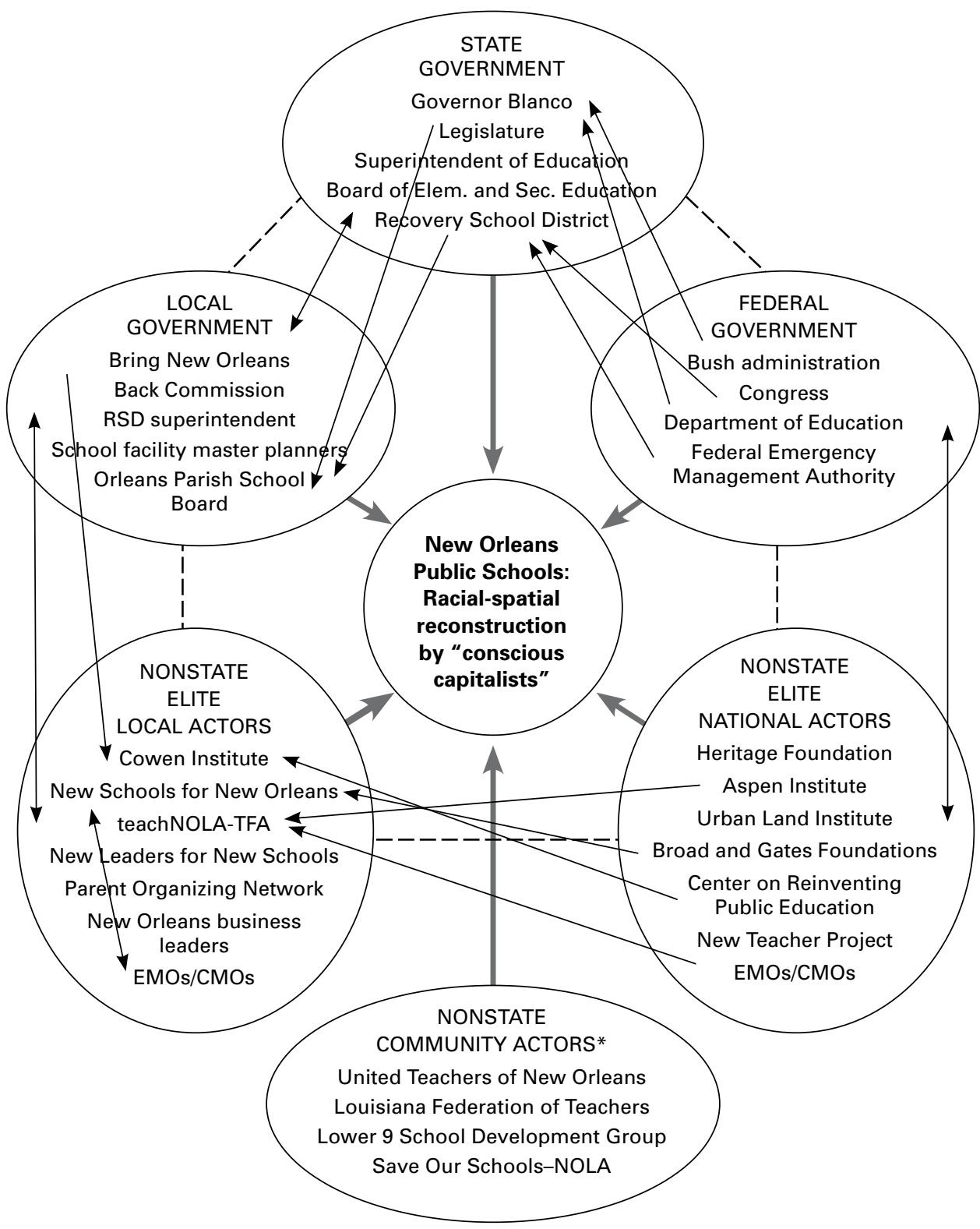

Notes: In other work, I more fully elaborate on community-based grassroots organizations within racially oppressed communities and the role they have played in challenging the current direction of New Orleans' racial-spatial reconstruction (see Buras, 2009, 2011a, 2011b 2011c, forthcoming; Buras et al., 2010). The arrows indicate lines of influence. The dotted lines indicate the conscious capitalist network.

Copyright $\odot$ Kristen L. Buras 
time pertains to relationships between objects and depends on what is being observed, why it is being observed, and who is doing the observing. There are multiple possible geometries depending on one's point of reference: the flow and movement of students from homes to schools. Relational space-time is representative of the past, present, and future swirling through and across space; rather than referring to what exists at a single point in time, it requires an aesthetic reading of where "mathematics, poetry, and music converge if not merge" (Harvey, 2006, p. 124): sitting in a newly renovated school and reminiscing about its past incarnations while seeing, through a window, a razed building where a future high school could have resided. Intersecting this matrix is another series of spatial frames: perceived space (as sensed through sight, sound, and touch), conceived space (as envisioned or represented), and lived space (infused with complex meanings generated from daily life, emotion, experience, and imagination) (Harvey, 2006; Lefebvre, 1974).

Taken together, these spatial frames illuminate the stakes of particular policy choices and put in sharp relief whose interests are most squarely served by current reforms and the urban space economy they produce. Understanding the policy ecology at the heart of educational reform in New Orleans is the central focus of this article. Drawing on and extending Harvey's (2006) theory of spatial politics and uneven geographical development under capitalism as well as Harris's (1995) theory surrounding the confluence of white power and property rights, I render transparent the racialized urban space economy of New Orleans and the fundamental part that school reform and conscious capitalism play in its production (see also Lipman, 2004; Omi \& Winant, 1994; Tate, 2008). The remaking of New Orleans' educational landscape after 2005 involved both systematic federal and state intervention and the actions of local education entrepreneurs and allies in city government. As such, I begin by mapping the web of influence from Washington, DC, to Louisiana's state capital in Baton Rouge and, ultimately, to New Orleans.

When Things Go South: Remaking the Racial, Economic, and Political Geography of New Orleans from Washington, DC, and Baton Rouge

In the mid-1990s, Cecil Picard-a member of the Louisiana state legislature who later became state superintendent of education-helped pass SB1305, which allowed charter schools in several of the state's school districts for a five-year trial period. This trial was only a shadow of what ultimately was to happen in New Orleans. To say that things went South in August 2005 alludes to the devastation of homes, schools, and neighborhoods as well as a relative geographic description of how monies and policies traveled from Washington to Baton Rouge and from Baton Rouge to New Orleans. Within days of the hurricane's strike on August 29, 2005, the conservative Heritage Foundation had begun issuing reports on "principled solutions for rebuilding lives and communities" on the Gulf Coast. In a report on September 12, it warned against 
Congress taking any steps that would "cause dollars to be used inefficiently" (Meese, Butler, \& Holmes, 2005, p. 1). Infused with the language of choice, entrepreneurialism, and markets, the Heritage Foundation offered the following guidelines for education:

New approaches to public policy issues such as enhanced choice in public school education should be the norm ... The critical need now is to encourage investors and entrepreneurs to seek new opportunities within these cities. Bureaucrats cannot do that. The key is to encourage private-sector creativity-for example, by declaring New Orleans and other severely damaged areas "Opportunity Zones." (Meese et al., 2005, p. 1)

Conscious capitalists conceived of the Gulf Coast, particularly the city of New Orleans, as an experimental space for deregulation, so-called innovation, and private entrepreneurial investment.

Three days after the Heritage Foundation report was issued, President George W. Bush (2005) delivered a national address from Jackson Square and urged that rebuilding efforts address "deep, persistent poverty in the region," a condition that "has roots in a history of racial discrimination" (para. 17). His answer: Congress should create a Gulf Opportunity Zone in Louisiana, Mississippi, and Alabama where the government "will take the side of entrepreneurs as they lead the economic revival of the Gulf Region" (para. 20). The very next day, Heritage followed up with "how to turn the president's Gulf Coast pledge into reality," stressing that "Congress should use existing federal charter school funding to encourage the development of charter schools" (Butler et al., 2005, para. 24). Such political-economic reconstruction of southern space, or regional zoning, was a federal mandate for state leaders-one soon to be bolstered by political pressure and strategic funding.

State leaders in Louisiana had plans of their own. A displaced representative of the Louisiana Federation of Teachers (LFT) ${ }^{4}$ reported receiving a call from Superintendent Picard even before the Federal Emergency Management Agency (FEMA) had hit the ground to address the crisis unfolding in New Orleans, where residents were stranded and dying in the hurricane's wake. The LFT representative recalled Picard saying:

The schools are going to be closed for at least a year. I mean, it's bad, but at the end of it all, we are going to have a brand new school system and it's going to be the bright new city of great opportunity for all children ... New Orleans is going to be a much smaller city because the folks that have been in New Orleans, the poor, have had no opportunities and now they are arriving in places [that promise much more]."

On one hand, New Orleans was destined to be a new city with educational opportunity for all children; on the other, it was going to be smaller with fewer poor people. These two maps of the future were irreconcilable and betrayed deeper contradictions. Which map would be the blueprint? 
A makeshift headquarters was set up in Baton Rouge for high-ranking state officials to reengineer the city. There was an immediate attempt to install Rod Paige, Bush's former secretary of education, as superintendent of education in Orleans Parish; however, according to an LFT representative, it failed because a supermajority vote of the Orleans Parish School Board was required but not secured. Nonetheless, the move for Paige signaled federal influence. Even more alarming, according to this representative, was that there was talk of "the social reengineering of a [Republican] city." In other words, there were political aspirations (some of which have come to pass) that New Orleans could be racially reconstructed so that the largely black Democratic stronghold of New Orleans would be weakened and the state's white Republican forces could have greater electoral sway; this would also have implications for local politics, shifting the racial balance of constituencies. In fact, a study in 2008 revealed that "the number of voters in the New Orleans area has fallen sharply, with African-Americans and registered Democrats losing the most ground" (Krupa, 2008, para. 1). ${ }^{5}$ The potential for radical shifts in the political landscape could have provided context for Picard's geographic imagination-did the poor (and black) residents not want to return, or were they not wanted back?

In November 2005, Louisiana governor Kathleen Blanco called a special legislative session in Baton Rouge. One LFT representative recalled, "We were hearing rumors that of all the things we could concentrate on [after] the greatest national disaster to hit a state or city-we're going to concentrate on school reform." After hearing about a potential state takeover of New Orleans schools, the LFT approached Blanco, who reportedly assured the organization that "everything was going to be fine." That legislative session became the occasion for passing Act 35, which redefined what constituted a "failing" school so that most of the New Orleans public schools could be deemed failing and placed in a state-run Recovery School District. Act 35 enabled 107 of the 128 schools to be folded into the RSD, whereas only thirteen schools could have been assumed before the legislation was passed (UTNO et al., 2006).

On the floor of the state legislature where the bill was circulating, an LFT representative asked why all of a sudden the denotation of failure had shifted upward, with test score cutoffs now just below the state average (that is, shifting from 60 to just below 87.4), and what exactly a "failing school" was. A white suburban senator reportedly responded, "A failing school is whatever we say it is." The LFT representative reflected on the meaning of the senator's statement:

The definitions are as we define them and the process is not driven by any kind of real data. It's driven by the powers, and the powers now had a very clear charge. And the charge was these schools are going to be taken over and they're going to be reformed, and they're going to be sold out, they're going to be chartered.

This exercise of raw power, revealing the indeterminate nature of the law and its malleability in serving dominant interests (Crenshaw, Gotanda, Pel- 
ler, \& Thomas, 1995), has been a central dynamic of educational reform in New Orleans. The circuit of power was not limited to Baton Rouge alone. It seems that, figuratively, Governor Blanco had the gun placed to her head by federal officials. An LFT representative said that the options presented to her were limited: "You're either going to turn [New Orleans] this way, it's going to become the largest experiment for charter schools-we're going to reengineer this, or you're not going to get the money [for reconstruction]."

Around this same period in 2005, Blanco signed Executive Orders 58 and 79 suspending certain provisions of charter school law, such as the need to consult and obtain the votes of affected faculty, staff, and parents before converting an existing public school into a charter school (LFT \& AFT, 2007). In a letter regarding the executive orders, the LFT expressed a number of fundamental democratic concerns:

Current charter school law provides for a community and faculty buy-in expressed by a favorable vote by both for a very good reason. The success of such an experimental school is largely dependent upon this active buy-in . . Teachers who wish to return to their now "forced-charter" schools must first accept the vacating of their negotiated contract, forfeiture of many legal rights, and embrace conditions of employment imposed upon them. They must also accept a unilaterally developed education plan spelled out in the charter application. Otherwise, these dedicated professionals cannot return.

Even more crucially, teachers "may have served with . . . commitment for decades only to see their sense of place and their careers snatched from them." Ultimately, the letter concludes, "a charter school decree . . . disenfranchises the stakeholders" (LFT, 2005). Such decrees were executed with a speed, precision, and scope that are terrifying. And disenfranchisement was not a byproduct-it was a goal.

Strategic conversations about the development of "human capital" in New Orleans (read: teachers) were proceeding simultaneously in Washington, DC, at the Aspen Institute, a self-described nonpartisan education and policy studies institute headed by Walter Isaacson (Aspen Institute, n.d.). Born in New Orleans, Isaacson worked for the local Times-Picayune newspaper and later as CEO of CNN. In 2003 he became president and CEO of the Aspen Institute. In addition, he serves as chairman of the board of Teach for America, which recruits college graduates who are not yet certified as teachers to teach in urban schools. ${ }^{6}$ As a witness to exchanges at the Aspen Institute in Washington, an LFT representative pondered the dominant discourse there:

We have a problem with teaching, the sustainability of the model. What do you do with the pension issue? The cost issues associated with it? Health care? We all know as teachers get older the cost of health care [rises]. What if we have a teacher quota: it is five years. Young people brought from quality universities, recruited by TFA [Teach for America], who would come. Until they decided 
what they really wanted to do with their lives, they would teach. There is no expectation of a pension. They would do this service.

On November 30, 2005, the announcement went out: 7,500 New Orleans teachers and school employees were informed that they would be fired and lose health insurance on January 31, 2006 (LFT \& AFT, 2007; UTNO, LFT, \& AFT, 2007a). In a piece titled "Go Southeast, Young Man," Isaacson (2006) lauded the unfolding educational innovations as a "civic revival," writing, "A system of competing charter schools has sprung up, nurtured by the state and fostered in Washington" (para. 11). It did not feel like a revival to veteran teachers. They had been fired en masse without due process and without any regard for either their contributions as educators or their hard-won rights and entitlements. When the New Orleans Public School system was dissolved and reorganized as a mere shadow of itself, and the state-run RSD was installed, veteran teachers who had worked for twenty to thirty years effectively lost all protections and entitlements guaranteed by UTNO's collective bargaining agreement. That is to say, the collective bargaining agreement was nullified because the district with which the agreement was negotiated no longer existed. This was unconscionable, but the state had no intention of rectifying it; rather, the state had engineered it.

One major issue was related to the cost of health insurance for those teachers and retirees who remained in the revamped system: premiums threatened to rise to over $\$ 1,000$ per month. As an LFT representative recounted, during the infamous November legislative session, two elderly, retired teachers in their eighties planned a trip to Baton Rouge to request appropriations to offset escalating premiums:

It was getting toward the end [of the session] and . . there was no quorum. So you had these old folks sitting in there with their nice little ties on, taught for thirty-five years each in the system, and they are going to tell them there is not going to be a meeting [without a quorum]. Now of course the administration brought them around to meet different people ... There were about ten of them [legislators] that came out. "Oh, something will work out." The bottom line is, nothing did. There was no money and the increases occurred.

The representative contended, "There is still no willingness to accept responsibility that you broke something down . . . People work their entire lives. You have an obligation. They had the expectation . . . This is a moral imperative." Meanwhile, despite the inhumane and criminal nature of their actions, many state legislators at the session donned buttons on their shirts that read "Rebuild It Right." Plans in Washington and Baton Rouge to oust vested, unionized, experienced teachers who were "expensive" and to recruit exploitable and cheap itinerant teachers with little expectation of benefits, were under way in New Orleans.

Another demonstration of unbridled power was exemplified when Lisa Keeling, a teacher for twenty-one years, returned after a period of displace- 
ment to teach at her former school. Yet, when Keeling arrived at school, she was greeted by a principal she did not recognize who asked what she was doing there (LFT, n.d.). According to an LFT representative, she was informed, "You don't work here anymore. But since you're here, why don't you get your stuff out." Her school had been taken over and chartered without teacher or community input. One can only imagine what it must have been like for Keeling to reenter this lived space, where she had countless memories of students and years of emotional attachment, only to discover that the one place that felt like home had been taken over and completely reconstituted. Such a moment crystallizes the meaning of accumulation by dispossession. To educational privatizers, the school was conceived as an empty shell ripe for transformation. But for Keeling, its hallways were pathways to a past she knew well, its present was painfully unrecognizable, and the future she imagined returning to was stolen. Keeling made her way north to the legislative session where she, too, was rebuffed.

The federal government created a Gulf Opportunity Zone, while President Bush spoke of addressing persistent inequities in the region. State officials in Louisiana alluded to building a bright new city and better schools for all children. Despite this socially conscious discourse, however, the flow of money and corresponding legislation evidenced a very different set of commitments. As their actions reveal, federal and state authorities in alliance with national policy actors sought to construct an urban space economy in New Orleans that served the interests of education entrepreneurs far more than the students, parents, and veteran teachers presumably at the center of reform. I argue that the racial and spatial dimensions of the project were evident-black veteran teachers were to be removed and replaced; their "sense of place" was to be snatched in the most literal sense.

\section{The Bring New Orleans Back Commission?}

In addition to understanding the federal and state roles, it is equally essential to understand the roles of local government and education entrepreneurs in advancing racial-economic reconstruction and the ways in which national policy actors supported reform initiatives on the ground in New Orleans. Beyond Baton Rouge, the dynamics of reform were likewise unfolding in New Orleans. In October 2005, Mayor Ray Nagin established the Bring New Orleans Back Commission (BNOB). Similar to Blanco's Louisiana Recovery Authority, BNOB's leaders included business elites (Buras, 2005). Among the appointees was James Reiss, a shipping and real estate mogul and chair of New Orleans Business Council, who declared, "Those who want to see this city rebuilt want to see it done in a completely different way: demographically, politically, and economically" (Cooper, 2005). Joseph Canizaro, another appointee and real estate multimillionaire, connected BNOB with the Urban Land Institute, which raised $\$ 1$ million to assist in rebuilding the Gulf Coast. This fund was 
initiated with a stipend from its J. C. Nichols Prize for Visionaries in Urban Development program. Notably, Nichols "was an influential real estate "pioneer' from Kansas City . . . who played a key role in promoting the use of racial covenants ... to keep African Americans . . . out of neighborhoods" (Arena, 2005, para. 5). In this way, BNOB evidenced a deeply relational and disturbing conception of space and time. To Bring New Orleans Back was really to tap a legacy of racial exclusion that stretched far and wide and to invoke this past as the city's future-a bright new city where whiteness as property will pass as socially responsible land use.

A range of subcommittees were constituted under BNOB, among them city planning, economic development, culture, and education, and each was tasked with envisioning and formulating a component of the larger plan for reconstruction. Headed by Tulane University president Scott Cowen, BNOB's education committee issued its plan in January 2006, advocating a "world-class public education" in the form of an all-charter school district. Using an educational network model, providers would operate groups of charter schools coordinated by network managers, and principals would be given oversight over budgets, hiring, and firing. This would be a portfolio district, a system of schools rather than a school system traditionally controlled by a presumably inefficient central office (BNOB, 2006).

BNOB's education committee made two notable recommendations: first, the district create a fair, rules-based system for placing students in their school of choice (p. 16); second, the district design a comprehensive scorecard to assess school and network performance and make scorecard results publicly available (BNOB, 2006, p. 18). These recommendations are particularly significant because they have never been implemented. The lack of these two items-fairness in student access and accountability in charter school performance-is noteworthy since they are the aspects of school choice that ensure democratic processes and thus could have been policy levers leading to greater oversight.

Many on the education committee agreed that free-market schooling was indeed the way forward, including President Cowen, Leslie Jacobs, Cecil Picard, and Mary Garton, executive director of Teach for America of Greater New Orleans. The stakeholder advisory committee that supported BNOB's educational effort also included some conspicuous figures: Steven Bingler, owner of Concordia architects, a firm with stakes in consulting and school building contracts; Brian Riedlinger, who would manage a network of charter schools; and Kathy Riedlinger, who would act as principal at a selective admissions charter school. The committee also touted its consultation of "top education experts" such as Wendy Kopp, Teach for America's founder; Mike Feinberg, founder of the Knowledge Is Power Program (KIPP); and Sarah Usdin, a founding partner of the New Teacher Project and soon-to-form New Schools for New Orleans (NSNO), a charter school organization. Moreover, it consulted with the Gates Foundation, Broad Foundation, and Annenberg Insti- 
tute-groups that would later support the materialization of BNOB's vision either politically or financially.

As BNOB's plans were being issued, the federal government had already begun providing millions of dollars for the establishment of charter schools in New Orleans (\$45 million in the first ten months after the storm) (UTNO et al., 2006). Meanwhile, Paul Hill and his colleague Jane Hannaway (2006) issued a report on schooling in New Orleans for the Urban Institute. Their view was unequivocal: "The leadership of the state of Louisiana and the city of New Orleans should treat the school system as a laboratory" (p. 11).

\section{The Cowen Institute for Public Education Initiatives: New Schools, New Teachers, and New Leaders for New Orleans}

The actions of federal, state, and local government created an opportunistic space into which education entrepreneurs quickly stepped. In fact, the role of elite nongovernmental policy actors in remapping the city's schools was fundamental, including an entrepreneurial university and an array of locally situated, but nationally funded, charter school and alternative teacher recruitment reform organizations-all of which aimed to advance what was portrayed as an innovative experiment in reengineering public education.

In its report, BNOB's education committee suggested the need to transform itself into an "Implementation Oversight Committee" (BNOB, 2006, p. 36). Enter the Cowen Institute for Public Education Initiatives at Tulane University, which provides shelter for a host of pro-charter school and alternative teacher recruitment organizations in New Orleans. A Cowen Institute representative explained that the links between BNOB's education committee and the institute were never part of a preordained plan but, rather, evolved organically and for strategic purposes. When the committee's report was issued in January 2006 and hailed as a national "blueprint for what education reform looks like," a mayoral election was on the horizon and there were concerns that the blueprint could get "lost in the shuffle," particularly if Nagin, who instituted BNOB, lost at the polls.

A more serious concern pertained to negative public perceptions of $\mathrm{BNOB}$ and the need to strategically disassociate the educational blueprint from its origins, even as its content remained unchanged. At the grassroots level, there was an increasing sense that the BNOB agenda was antithetical to the interests of poor and working-class African Americans who wished to return to the city. A representative of the Cowen Institute shared:

We recognized that no matter what happened, it [the education blueprint] couldn't be housed within the mayor's office ... One of the [BNOB] Commission meetings . . . was a presentation about where people could live . . It was a public meeting [with 600 residents] and there was this big map with dots, and it was like you're looking-"That red dot is actually where I live and red means that's going to be green space"... Everyone then thought of the land use plan 
... [And] anything attached to [BNOB] was almost like a four-letter word . . .

They were so up in arms about shrinking New Orleans's footprint.

For this reason, even if the education blueprint was part of a more comprehensive plan to take over and commodify public assets in black neighborhoods, it had to be given new grounding.

In the end, as a Cowen representative explained, education reformers recognized that Tulane could "move something along," particularly since it is "the largest employer in the city-we have more political capital in the state and DC than any other entity." The need was all the more pressing as "new nonprofits were arising," such as New Schools for New Orleans and New Leaders for New Schools (NLNS), "yet [without] a lot of coordination between anybody." It was envisaged that Tulane could be a "convener of all of these." The Cowen Institute opened its doors in March 2007, fashioning itself as an "action-oriented think tank that informs and advances solutions-through policies, programs, and partnerships-to eliminate the challenges impeding the success of K-12 education" (e.g., see Cowen Institute, 2010, p. i).

An oft-repeated exultation at the Cowen Institute is that no one there has an educational background. This is seen as positive because, according to an institute representative, in schools of education

they spend all of their research capacity and money and resources on academic theory and curriculum ... But the problem is over here ... [The schools] can't even buy books because the money is being mismanaged, or the principals can't even fire bad teachers ... That's about management. That's not about academics and curriculum.

By contrast, the staff at the Cowen Institute is "able to think about [education] from a business perspective because we have MBAs working who've studied corporate America and franchising."

According to the Cowen Institute, the central problem is a managerial one. It is not that there is no money to buy books, or that teachers are doing badly because there are no books; instead it is an issue of bureaucratic governance, and the theory is that if schools are open to market forces, they will improve. Therefore, one of the primary areas where the Cowen Institute has focused its resources is governance. For example, the institute generated a series of white papers on models of educational management (Cowen, 2009a, 2009b, 2009c). While arguments for and against particular models are presented, the overarching impression is that local school boards are politicized and ineffective and that state control, some level of mayoral control, or appointed leadership is preferable; a central office generates fraud and waste while decentralized decision making in budgeting, personnel, and school operations leads to improved outcomes and cost reduction; and, finally, charter schools are the wave of the future and state-level authorization, seemingly insulated from local matters, is likely to be a more impartial and productive process. 
A more historicized and relational frame betrays the notion that the problem is a managerial one. Given that since the late 1970 s the mayor, city council, and board of education in New Orleans have been more black, specifically Afro-Creole, than white (DeVore \& Logsdon, 1991; Parent, 2004), this notion harkens back to Reconstruction-era discourse that African Americans have no capacity for self-government. While past instances of financial mismanagement and fraud in NOPS should not be dismissed, we must also recall the legacy of racialized disinvestment and neglect that plagued the schools, engendered shortfalls in the millions, and made it all but impossible to balance the budget (Buras, 2007).

When I questioned representatives at the Cowen Institute about its mission as an "action-oriented think tank," there was consistent denial that it was engaged in political work (e.g., see Cowen Institute, 2010, p. i). One representative underscored, "We don't advocate for an all-charter system because we don't feel there's adequate research to indicate that charters will outperform noncharters." Instead representatives present the institute as an "honest broker" and an "objective observer." However, as soon as one steps through its doors and perceives the space, this presentation is challenged. Just beyond the main desk is an incubation room for charter schools. The fact is, the Cowen Institute provides free room and board to some of the most aggressive procharter school groups and alternative teacher recruitment organizations in the city, including: New Schools for New Orleans, a charter school incubator; an alternative teacher recruitment triad comprised of teachNOLA, Teach for America, and the New Teacher Project; New Leaders for New Schools, a recruitment and professional development project for principals and charter school board members; and the New Orleans Parent Organizing Network, a group that organizes parents around school choice.

When asked to account for this contradiction, one institute representative explained:

I think the idea was just that Cowen had a lot of space and there were a number of organizations that needed space ... The idea was to bring a lot of groups together that were working in the reform area so that there would be more back and forth around, "What are you doing?"

By sharing space, another representative said, the institute is "able to find out what's happening in the trenches without being in the trenches."

Whether explicitly acknowledged or not, the Cowen Institute is indeed in the trenches. I assert that there are no circumstances under which an institution as elite as Tulane University would provide shelter for organizations without a congruence between the Cowen Institute's mission and their purposes. Nor was it a financial necessity for these groups to rely on the institute for space, particularly since NSNO, Teach for America, and NLNS received \$17.5 million from the Broad, Gates, and Doris and Donald Fisher foundations in 
December 2007 (Maxwell, 2007; Scott, 2009). Moreover, the spatial politics are apparent: the Cowen Institute and its partners are co-located because they share an agenda, and it does not seem by chance that they are based uptown under the auspices of Tulane, a historically white institution, while the actions of these organizations have serious consequences for black children and families who largely live downtown.

\section{Initiatives Housed at the Cowen Institute}

New Schools for New Orleans (NSNO), founded in early 2006, is committed to charter school and human capital development. More specifically, its strategy is fivefold as it seeks founders to start charter schools, principals to lead charter schools, teachers to teach in charter schools, members to serve on charter school boards, and investors and philanthropists to contribute to these efforts (see NSNO 2008a, 2008b, 2008c). For example, its Incubation Program provides "resources to new school founders in the year before opening" and announces, "If you are an experienced, dynamic, entrepreneurial educator . . then this is your chance" (NSNO, n.d., p. 7). From 2007 to 2010, the organization launched ten charter schools, seeded three local charter management organizations, and provided twenty-one start-up grants that have supported over 90 percent of newly approved charter schools (NSNO, 2010b).

NSNO has partnered with the national organization New Leaders for New Schools (NLNS) to recruit, train, and place principals and other school leaders in the public schools of New Orleans. "In schools, just as with businesses, strong leadership breeds results," reads its literature (NSNO, 2008a, para 1). NSNO (2010b) boasts the training of thirty-six charter school boards for over 90 percent of charter schools in the city. To facilitate this effort, NLNS maintains a Board Bank that includes the names and resumes of parties wishing to serve on charter school boards and makes them available to schools. The qualifications that NLNS expects from Board Bank members reveal the raced and classed dimensions of charter school governance:

- Expertise in law, real estate, financial management, governance, marketing, fund raising, community organizing/outreach, education, or strategic planning

- Personal experience with entrepreneurship

- Willingness to leverage personal and professional networks on behalf of the school (NSNO, 2010a)

It is safe to say that very few working-class parents-most of whom are African American in New Orleans-command the social, economic, and political capital, much less the spare time, to participate on such a board. In this way, whiteness is perpetuated as a form of property, as those who possess forms of capital closely linked to class and race status benefit from and exercise disproportionate power over public schools attended by African American students. 
An additional "human capital" initiative is teachNOLA, a teacher recruitment collaboration with the New Teacher Project, a national organization that "works with clients on a fee-for-service basis" to place "alternate route teachers" in "high-need schools" (TNTP, 2010). The New Teacher Project itself won the Social Capitalist Award in 2008 from Fast Company magazine (TNTP, 2007). Building on this ethos, teachNOLA claims to have "eliminated the city's teaching shortage so that there can now be an increased focus on long-term quality" (NSNO, 2010b). Skirting the fact that the shortage was engineered through state policy, teachNOLA has placed new teachers in 96 percent of the city's charter schools over the past three years (NSNO, 2010b).

New Schools for New Orleans also seeded the New Orleans Parent Organizing Network, tasked with providing information to parents on school choice. Among the network's projects was the ninety-page New Orleans Parents' Guide (NSNO, 2007). The guide suggests that parents seeking to enroll a child determine which documents are required by a given school in order to apply or register, including report cards and test scores that "can help properly place [italics added] your child" (p. 9). Parents are also offered guidance on how to "choose" a school: review some sixty-eight pages of information to "identify schools," then arrange visits, tour the schools, observe classes, interview principals and teachers, and possibly apply-that is, if one's child qualifies and the application deadline has not passed (pp. 9-15).

Clearly, such processes are navigated more easily by parents with surplus time, readily accessible transportation, intact documents, physically undamaged homes, monetary resources, and education, thereby advantaging more privileged families as well as families with "able" and "high-achieving" children (see also Apple, 2001; Ball, 2003). This provokes questions about student admission and familial access to what are supposed to be public spaces and institutions. NSNO consistently states its support for chartering "public" and "open enrollment schools," but such qualifiers serve to mask exclusionary practices that are occurring (NSNO, n.d.). While open enrollment may refer to schools that do not rely on traditional neighborhood attendance boundaries for student admission but instead admit students citywide, this does not mean that such schools are necessarily open access with respect to admissions policies.

Whether in terms of how boards are constituted or in terms of how student and familial challenges are addressed, the charter school movement in New Orleans is closely bound to the protection of whiteness as property, as the clearest beneficiaries are upper-class white (and a few black) entrepreneurs who seek to capitalize on public assets for their own advancement while dispossessing the very communities the schools are supposed to serve. A veteran teacher reflected on the mass firing of educators and the charter-driven state takeover:

I explain the dismissal as a hostile takeover, a power struggle [by] those who wanted the control of the millions of dollars that was involved in education in Orleans Parish ... This was primarily controlled by African Americans who were 
able to allot contracts and do all the necessary things that they needed to do to control their own destiny. The powers that be [were] not pleased with that. They were looking for years to find ways to wrest control back from the district because the district served a majority African American population.

Notably, while charter school advocates frequently refer to fraud that predated current reforms, there is much less talk about the fraudulent manner in which the schools were taken over or the ways in which their charterization enables the channeling of public monies into private hands through "legal" means.

\section{The Recovery School District and School Facilities Master Plan:} The Master's Plan Indeed

The state-run Recovery School District has been a key partner in advancing the project of conscious capitalism, turning over public schools to education entrepreneurs for a "fresh start." Historic and willfully fostered racial inequities prepared the grounds for their assault on black schools and neighborhoods, while the School Facilities Master Plan (SFMP) provides the blueprint for racial-spatial reconstruction of New Orleans' urban space economy.

In 2006, many students in the RSD, who were nearly twice as likely to be lowincome, were still without teachers, books, buildings, and school buses (Ritea, 2006; UTNO et al., 2006). By January 2007, the Southern Institute for Education and Research declared that New Orleans had "the most balkanized school system in North America" (McElroy, 2007). After Cecil Picard passed away, Paul Pastorek-a corporate attorney and former member of BESE-took his place as state superintendent of education (Font, 2009). While schoolchildren in New Orleans went without books, Pastorek became the highest-paid state education superintendent in the South, making a salary of $\$ 411,000$. Paul Vallas, who was partly responsible for the closure and privatization of schools in Chicago and Philadelphia, assumed the role of RSD superintendent for a salary of $\$ 252,689$ (Thevenot, 2009). Those responsible for leading the project of accumulation by dispossession would be well paid for their labor, while the needs of veteran teachers and students would be neglected, if not consciously dismissed.

The start of the school year in 2007 was no more promising. By this time, the city had eighty-two public schools, and forty-two were charters-most of them with selective admissions criteria, enrollment caps, and other barriers to entry (UTNO, LFT, \& AFT, 2007b). The development of the SFMP for Orleans Parish by school officials and private consultants was also under way from October 2007 to July 2008 (RSD \& NOPS, 2008a). The SFMP determines which schools remain open, merit renovation or new construction, or get closeddecisions with clear implications for working-class and middle-class communities of color who resided where destruction from the hurricane was most substantial. ${ }^{7}$ It landbanks more than sixty existing schools; that is, the schools are 
either to be "retained" (remain closed indefinitely), "redeveloped," or "converted" for public or private uses (RSD \& NOPS, 2008a, p. 58). Each of these possibilities has direct and disparate financial consequences for entrepreneurs and targeted schools and communities.

According to the RSD and OPSB, "The creation of the master plan presented a unique opportunity to engage the community" (RSD \& NOPS, 2008a, p. 38). However, rather than using the language of community, the plan is filled with terms such as, inputs, outputs, Facility Condition Index, population trends, and recovery profiles. Working-class communities of color were denied a voice in shaping the SFMP in any meaningful way. After a series of public meetings between October 2007 and July 2008-meetings that many residents described as a farce, since decision making was already under way by master planners-the SFMP "draft" was released in August 2008 (RSD \& NOPS, 2008a). There was to be a thirty-day window of public comment before the final plan was set. Around this time, Hurricanes Gustav and Ike prompted another round of evacuations. Concerned about parents' and students' ability to weigh in before the deadline, Save Our Schools-New Orleans, Louisiana (SOSNOLA) petitioned the RSD for a ninety-day extension of the comment period to January 1, 2009. The petition argued that citizens needed additional time "to hold meaningful conversations within . . communities so as to make informed decisions regarding our thoughts on the plan" and concluded with the line, "OUR Schools. OUR Future. OUR plans." As one resident wrote with his signature on the petition, "To ram this Master Plan through with such a brief public comment period is unconscionable" (SOSNOLA, 2008). However, the planners were not moved by the petition; they extended the period of comment by only two weeks. In the end, a representative with SOSNOLA said, "The schools that are going to be rebuilt under the [SFMP] are basically at the whim of the superintendent and the folks who are in charge." Dismissing the request for additional time for public comment, the RSD released its amendments to the draft master plan in early November 2008 (RSD \& NOPS, 2008b).

The SFMP is intimately related to the production of New Orleans' urban space economy; the plan patently reflects the racial, economic, and spatial vision of the master planners, educational entrepreneurs, and their uptown neighborhood allies rather than the city imagined by black working-class neighborhood residents. First and foremost, the SFMP adopted an absolute and highly technical conception of space-one divorced from the lived experiences and historical relations that communities share with long-standing neighborhood schools. This ahistorical focus on facilities can be seen in the blueprint, which states that "the master plan describes the maintenance and development of an infrastructure and physical plants that will support the needs of educational delivery" (RSD \& NOPS, 2008a, p. 13).

Secondly, the plan weds demography and topography to produce accumulation by dispossession (Harvey, 2006). One of the "selection parameters" for deter- 
mining where schools will be opened, renovated, or built is enrollment projections, which do not account for the ways in which class, race, and state policy have enabled and disabled the reconstruction of specific neighborhoods-or the fact that it is even harder to return and rebuild neighborhoods when there is no school nearby. The plan fails to account for the ways in which the SFMP itself plays a fundamental role in shaping the deconstruction and reconstruction of communities along race- and class-based lines.

Third, the geography of where schools will be landbanked, demolished, or built is wholly racialized and connected to elite conceptions of a less populous city. One community member expressed concern about the master planning process and possible closure of the only open-access high school in the neighborhood in this way: "What it has gotten to is the fact that if we close down all of the high schools, and you know your children have nowhere to go to school, then you'll leave. They've tried everything that they can to get people out [of this city].”

Finally, an uneven urban space economy was produced through the phased nature of the blueprint-an example of what Lipsitz (2007) calls the "spatialization of race" and the "racialization of space." Although the SFMP includes six different building phases, only Phase 1 is actually funded. The estimated cost of the entire plan is approximately $\$ 2$ billion, yet only $\$ 685$ million has been secured through FEMA and Community Development Block Grants. ${ }^{8}$ A representative of the grassroots parent organization SOSNOLA stated, "I call it Phase 1 and Phase Never." The reality is, for the foreseeable future only schools in Phase 1 will receive support for rebuilding, which means only certain neighborhoods will have schools. Even before the development of the SFMP, Cynthia Willard-Lewis, who represents downtown neighborhoods on the city council, warned, "The reality check is that the schools below Canal Street were X-ed off the map" (Tisserand, 2007, para. 35). In addition, phasing of the plan engendered a splintered spatial imaginary that divided communities from one another as each sought to secure a place in Phase 1 of the blueprint.

Sadly, a spatial analysis of the distribution of schools across the city does not require sophisticated use of geographic information systems; all that is needed is a pencil. Canal Street, which divides uptown from downtown and borders the French Quarter, not only demarcates natural high ground from vulnerable low ground and white space from black space, but it likewise marks a long history of racism, territorial segregation, and economic exploitation of black labor. For example, one of the major thoroughfares intersecting Canal Street is called St. Charles Avenue on the uptown side and Royal Street on the downtown side, a reminder of segregation. Today it is a stark dividing line that separates a high density of public schools relocated uptown under the SFMP (RSD $\&$ NOPS, 2008a) and the mere handful of public schools reopened or rebuilt downtown. Figure 3 shows the locations of the schools in New Orleans. Simply laying a pencil where the French Quarter divides uptown from downtown 


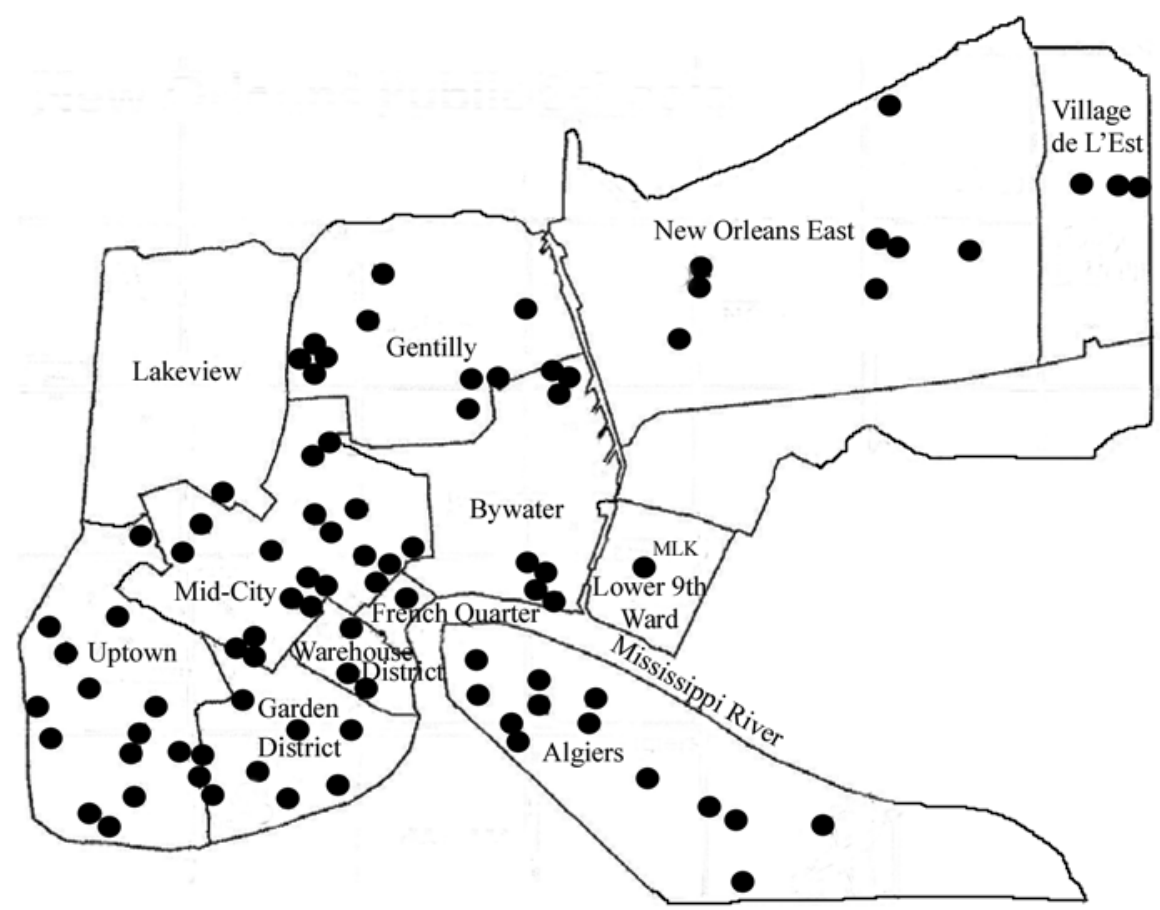

Sources: This figure was created using directories and reports from the Louisiana Department of Education, the Recovery School District, and the Orleans Parish School Board.

Notes: Bullets denote school locations. Area boundaries are based on planning districts designated by the New Orleans City Planning Commission.

Copyright (C) Kristen L. Buras

reveals the mass concentration of schools uptown and the gross absence of schools downtown, even though the majority of the students who attend public schools live in the downtown neighborhoods; downtown neighborhoods in Figure 3 include Bywater, the Lower 9th Ward, New Orleans East, and Village de L'Est. The spatialization of race and the racialization of space (Lipsitz, 2007) are clearly evident, particularly as public schools are geographically reorganized, commodified, and wedded to the perpetuation of racial and economic power and subordination.

To provide a very real glimpse into what is happening under the SFMP, I offer as an example the story of a particular school community in the Lower 9th Ward. This moves us from an overarching discussion of the SFMP's racialspatial politics to a living example of how the decisions of elite policy actors are affecting and dispossessing grassroots communities (for more examples, see Buras, forthcoming). 
Martin Luther King Elementary School in the Lower 9th Ward (see figure 3) was only rebuilt due to the civil disobedience of its principal, veteran teachers, and community members (Buras, 2011b, forthcoming). Predating current reforms by a decade, it was forced to charter-the only means for possibly reopening. Since its reopening, the school has reached capacity at eight hundred students, has a waiting list of over five hundred, and is running a small high school on its current campus.

As the Lower 9 School Development Group (L9SDG) attests, the neighborhood is in desperate need of a high school. Under the SFMP, three of the five schools that existed in the Lower 9th Ward either have been demolished or are slated for demolition, and a fourth has been indefinitely closed (RSD \& NOPS, 2008a). Yet the RSD received millions from FEMA for damage to these schools. This money was not allocated to the Lower 9th Ward, but instead it was placed in a general fund and is being used for other Phase 1 projects (L9SDG, 2010). Although Phase 2 includes a Lower 9th Ward high school, it is planned as just a meager $\$ 5$ million addition to King Elementary (RSD \& NOPS, 2008b). L9SDG formed to collect petitions from families for a proposed high school in the neighborhood. It also sponsored a billboard demanding RSD funding for neighborhood schools, which read, "Lower 9th Ward Stakeholders Ask ... Where's the Money?" A representative of the group asked, "Who made a decision that we didn't want a school back in this area? . . . To take my money and place it in some arbitrary fund and say we're going to do whatever we want to do-I think that's criminal" (see also Buras, 2011c, forthcoming; L9SDG, 2010). The struggle for a neighborhood high school continues at the time of this writing.

\section{Conclusion}

If this is the panacea for education, please visit this city and take a look at what's going on. Take a visit to these schools. Talk to the educators in this city ... because it's not all peaches and cream that you're reading about or hearing about.

UTNO affiliate

The race and class dynamics producing the urban space economy of New Orleans involve not only local policy actors but powerful actors at the state and federal levels as well. From nationally influential conservative foundations and the corresponding exercise of power by federal authorities, to Louisiana lawmakers and state education officials, to local politicians, business leaders, and educational entrepreneurs, an experimental plan for reconstructing the public schools of New Orleans was consciously envisioned and enacted. It is essential to understand this complex policy ecology and its effects on workingclass communities of color. The dispossession of such communities has bee $\mathrm{n}$ fostered through exclusionary decision making by elite policy makers and the capitalization of the public institutions on which these communities 
depend. At the same time, accumulation by dispossession has not advanced without resistance from affected grassroots communities (e.g., see Buras et al., 2010; Buras, forthcoming). Rather, they have critically assessed and challenged these circumstances by articulating their concerns and mobilizing against this assault-demanding, in essence, that whiteness as a form of property is exposed as racially exploitive and inequitably redistributive.

Ultimately, accumulation by dispossession is founded on and reinforces a disregard for teachers, students, and parents. Within the politics of conscious capitalism, educational entrepreneurs engage in conquest through takeover charter schools, producing an urban space economy that bolsters their own class and race interests. A veteran educator and representative of UTNO deemed Vallas, master planners, and charter school operators "functionaries of privatization," indicating that they spoke for "white men and all that entails, probably in its nastiest forms." The exercise of control is not only about where schools will go and who will manage them but, likewise, who will teach in them and who will attend them. This project of dispossession has required the racial-spatial removal and redistribution of entire populations-a project propelled by accumulative desires and a profound disregard for the accrued benefits and property rights of teachers, students, and parents. One veteran teacher attested:

It's all about the dollars . . . Our rights as teachers have been trampled upon . . . They are saying that they are revamping the schools or whatever. They get rid of everyone ... and they rehire whoever they want to rehire. In many cases, they replace veteran teachers with first-, second-, and third-year teachers.

The same goes for students. Accounts of formal exclusion from selectiveadmissions charter schools are common enough. But stories of informal exclusion and problems of access-targeted student recruitment, laborious application procedures and deadlines, enrollment caps, parental steering and harassment, "pushing out," and periodic dumping from presumably openaccess charter schools-are widespread. One veteran special education teacher specified:

Charter schools do not take special education students, per se. They try to find all kinds of ways to get around it. Some parents are just turned away. They [say], "We don't offer those services"... Then other students are turned away because they were behavior problems, because the grade point average isn't above a C.

Such are the politics of conscious capitalism.

In contradistinction, I would suggest that there are democratic and collective principles that should guide the reform of schools in New Orleans and other cities as well. These include ensuring public schools that are

- neighborhood-based, supporting the restoration and rebuilding of racially and economically oppressed communities along lines that are self-determined and inclusive 
- open access, without either formal or informal barriers to student enrollment and retention

- respectful of the contributions, rights, and benefits of veteran teachers who have been subjected to the loss of assets accrued through decades of public service

- prepared to recognize the teacher union in collectively representing the interests of veteran educators

- welcoming of substantive and democratic participation of grassroots communities in educational decision making, including plans for building and governing schools throughout the city

- born from governmental transparency and accountability in the allocation and use of public monies based on legitimate, sustained, and widespread community input

The materialization of this democratic vision will require ongoing grassroots struggle to redefine what counts as educational equity. As a part of this movement, veteran teachers, students, parents, and community organizers; cultural and educational organizations; and critical researchers established the Urban South Grassroots Research Collective for Public Education. The collective, which I cofounded and direct, develops and investigates questions focused on equity and accountability in public education. Countering the educational vision advocated by elite policy actors, the collective's research highlights the voices, experiences, and concerns of racially and economically dispossessed communities. The focus of this work is threefold: (1) government transparency, policy, and public education; (2) democratic curriculum, pedagogy, and assessment; and (3) grassroots school improvement and community engagement. By providing an alternative vision through locally and nationally disseminated research, combined with grassroots actions and initiatives, it may be possible to influence the existing ecology of educational policy making and unearth the concerning effects of public school privatization.

Critical research and ongoing activism in multiple spaces are crucial. What is currently happening in New Orleans is not socially conscious capitalism. It is simply unconscionable.

\section{Notes}

1. In the United States, Reconstruction was the period following the Civil War (18651877) during which southern whites sought to restore their racial power despite the emancipation of blacks. A similar period of massive resistance occurred during the civil rights movement of the mid-twentieth century, when whites attempted to defend inequitable racial conditions despite black protest. I use the term Reconstruction here to underscore the ways in which recent disaster in New Orleans provided the conditions for restoring white control over the city's largely black public school system (and other dimensions of urban infrastructure). This power had been partly compromised by white flight to surrounding suburbs after the civil rights movement and the increasing presence of black leaders in local government from the late 1970s to 2005. 
2. Given the highly politicized situation in New Orleans, I do not identify any of those I interviewed by name or by role, nor do I differentiate them from one another by pseudonym. I use representative to refer to more than one person within an organization and affiliate to refer to those associated with an organization outside of an official capacity.

3. UTNO is the local affiliate of the Louisiana Federation of Teachers. I interviewed union representatives from these organizations as well as veteran teachers affiliated with UTNO. Importantly, the views expressed by affiliated teachers reflect their experiences and were not offered as representations of the union's official position on educational reform in New Orleans. However, there was a great deal of confluence among viewpoints of veteran teachers and union representatives. UTNO has represented the majority of black veteran educators in the city for decades.

4. LFT is the state affiliate of the American Federation of Teachers, a national teacher union.

5. In fact, voter turnout in historically black areas of the city dropped almost 60 percent from 2003 to 2007, while turnout in largely white areas dropped only 27 to 36 percent during this same period. Statewide and citywide implications are equally apparent: "The days when local candidates could appeal to Orleans' overwhelmingly black electorate and receive a handful of white votes to win office may be a thing of the past" (Krupa, 2008, para. 23).

6. It should also be mentioned that Isaacson sits on Tulane University's board and was also appointed vice chair of Governor Blanco's Louisiana Recovery Authority, which included executives from banks, shipyards, investment firms, real estate, construction, architectural, and lumber companies, oil industries, and restaurants (Buras, 2005).

7. Two private firms were hired by the RSD to develop the SFMP-Parsons, a management and planning firm with a deficient construction history in Iraq, and Concordia, an architecture and planning firm founded by Steven Bingler, a member of the stakeholder advisory committee for the BNOB education committee and brother-in-law of Sarah Usdin, founder of NSNO (Myers, 2007; RSD, 2007). In the case of Parsons, U.S. taxpayers paid the firm $\$ 62$ million for its construction of the Baghdad Police Academy, which is notable for its shoddily built brick walls, cracking concrete, faulty electrical box wiring, and plumbing that leaked human waste through light fixtures and ceilings (Myers, 2007).

8. Senator Mary Landrieu made an announcement in August 2010 that FEMA will provide a $\$ 1.8$ billion grant to the RSD (Chang, 2010). This has intensified grassroots concerns over transparency and the politics of decision making and will shape the ongoing struggle over the SFMP.

\section{References}

Apple, M. W. (2001). Educating the "right" way: Markets, standards, God, and inequality. New York: RoutledgeFalmer.

Arena, J. (2005, November 23). The Urban Land Institute, J. C. Nichols, and the ethnic cleansing tradition. New Orleans Independent Media Center. Retrieved from http:// neworleans.indymedia.org/news/2005/11/6415.php

Aspen Institute. (n.d.). Walter Isaacson: President and CEO of the Aspen Institute. Retrieved from www.aspeninstitute.org/walterisaacson

Ball, S. J. (2003). Class strategies and the education market. London: RoutledgeFalmer.

Bring New Orleans Back Commission [BNOB]. (2006, January 17). Rebuilding and transforming: A plan for world-class public education in New Orleans. New Orleans: Author.

Buras, K. L. (2005). Katrina's early landfall: Exclusionary politics behind the restoration of New Orleans. Z Magazine, 18(12), 26-31. 
Buras, K. L. (2007). Benign neglect? Drowning yellow buses, racism, and disinvestment in the city that Bush forgot. In K. Saltman (Ed.), Schooling and the politics of disaster (pp. 103-122). New York: Routledge.

Buras, K. L. (2009). "We have to tell our story": Neo-griots, racial resistance, and schooling in the other South. Race Ethnicity and Education, 12(4), 427-453.

Buras, K. L. (2011a). "It's all about the dollars": Charter schools, educational policy, and the racial market in New Orleans. In W. Watkins (Ed.), The assault on public education. New York: Teachers College Press.

Buras, K. L. (2011b). “We're not going nowhere”: Race, urban space, and the struggle for King Elementary School in New Orleans. Manuscript submitted for publication.

Buras, K. L. (2011c). Where's our money, where's our high school? Questioning the master's plan for the Lower Ninth Ward of New Orleans. Z Magazine, 24(5).

Buras, K. L. (forthcoming). Charter schools, race, and southern urban space: Where the market meets grassroots resistance. New York: Routledge.

Buras, K. L., \& Apple, M. W. (2005). School choice, neoliberal promises, and unpromising evidence. Educational Policy, 19(3), 550-564.

Buras, K. L., Randels, J., Salaam, K. Y., \& Students at the Center. (2010). Pedagogy, policy, and the privatized city: Stories of dispossession and defiance from New Orleans. New York: Teachers College Press.

Bush, G. W. (2005, September 15). Text of Bush speech. Retrieved from www.cbsnews.com

Butler, S. M., Carafano, J. J., Fraser, A. A., Lips, D., Moffit, R. M., \& Utt, R. D. (2005, September 16). How to turn the president's Gulf Coast pledge into reality (Webmemo 848). Heritage Foundation. Retrieved from http://www.heritage.org/research/reports/2005/09/ how-to-turn-the-presidents-gulf-coast-pledge-into-reality

Carr, S. (2009, November 10). Grandmother struggles to navigate system. Times-Picayune. Retrieved from www.nola.com

Chang, C. (2010, August 26). \$1.8 billion from FEMA for Hurricane Katrina school rebuilding is "worth the wait," Sen. Mary Landrieu says. Times-Picayune. Retrieved from www .nola.com

Charter Revision Commission. (2010, January 28). Proceedings [Transcript]. Jacksonville, FL: Author.

Cooper, C. (2005, September 8). In Katrina's wake-Old-line families escape worst of floods and plot the future. Wall Street Journal, p. A1.

Cowen Institute. (2009a, November). Creating a governing framework for public education in New Orleans: School district political leadership. New Orleans: Author.

Cowen Institute. (2009b, November). Creating a governing framework for public education in New Orleans: The central office and the school. New Orleans: Author.

Cowen Institute. (2009c, November). Creating a governing framework for public education in New Orleans: Charter school authorizers and charter school governance. New Orleans: Author.

Cowen Institute. (2010). The state of public education in New Orleans. New Orleans: Author.

Crenshaw, K., Gotanda, N., Peller, G., \& Thomas, K. (Eds.). (1995). Critical race theory: The key writings that formed the movement. New York: New Press.

DeVore, D. E., \& Logsdon, J. (1991). Crescent City schools: Public education in New Orleans, 1841-1991. Lafayette: Center for Louisiana Studies, University of Southwestern Louisiana.

Font, P. (2009, March 9). The gospel according to Paul. Baton Rouge Business Report. Retrieved from www.businessreport.com

Harris, C. I. (1995). Whiteness as property. In K. Crenshaw, N. Gotanda, G. Peller, \& K. Thomas (Eds.), Critical race theory: The key writings that formed the movement (pp. 276291). New York: New Press.

Harvey, D. (1973). Social justice and the city. Baltimore: Johns Hopkins University Press. 
Harvey, D. (2006). Spaces of global capitalism: Towards a theory of uneven geographical development. New York: Verso.

Hill, P., Campbell, C., Menefee-Libery, D., Dusseault, B., DeArmond, M., \& Gross, B. (2009, October). Portfolio school districts for big cities: An interim report. Seattle: Center on Reinventing Public Education.

Hill, P., \& Hannaway, J. (2006, January). The future of public education in New Orleans. Washington, DC: Urban Institute.

Isaacson, W. (2006, June 8). Go southeast, young man. Aspen Institute. Retrieved from www .aspeninstitute.org/node/2953

Krupa, M. (2008, April 23). City's political landscape has shifted. Times-Picayune. Retrieved from www.nola.com

Kvale, S. (1996). InterViews: An introduction to qualitative research interviewing. Thousand Oaks, CA: Sage.

Lefebvre, H. (1974). The production of space (Donald Nicholson-Smith, Trans.). Malden, MA: Blackwell.

Lipman, P. (2004). High stakes education: Inequality, globalization, and urban school reform. New York: RoutledgeFalmer.

Lipsitz, G. (2007). The racialization of space and the spatialization of race: Theorizing the hidden architecture of landscape. Landscape Journal, 26(1), 10-23.

Louisiana Federation of Teachers [LFT]. (n.d.). Imagine just for a moment [Broadside]. Baton Rouge: Author.

Louisiana Federation of Teachers [LFT]. (2005, November 2). Letter to Blanco regarding Executive Orders 58 and 79. Baton Rouge: Author.

Louisiana Federation of Teachers [LFT] \& American Federation of Teachers [AFT]. (2007, January). The chronology: Scenario of a nightmare. Baton Rouge: Author.

Lower 9 School Development Group [L9SDG]. (2010, January 16). What is L9SDG? Retrieved from http://19sdg.blogspot.com/

Maxwell, L. A. (2007, December 13). Foundations donate millions to help New Orleans schools' recovery. Education Week. Retrieved from www.edweek.org

McElroy, E. J. (2007, January 30). Statement to friends of public education. Washington, DC: American Federation of Teachers.

Meese, E., Butler, S. M., \& Holmes, K. R. (2005, September 12). From tragedy to triumph: Principled solutions for rebuilding lives and communities. Washington, DC: Heritage Foundation.

Miester, M. (Ed.). (2010). The rise of conscious capitalism. Freeman, 26(2), 17.

Mirón, L. (2008). The urban school crisis in New Orleans: Pre- and post-Katrina perspectives. Journal of Education for Students Placed at Risk, 13, 238-258.

Myers, L. (2007, January 31). Did Iraq contractor fleece American taxpayers? Government report says flagship project was turned into hall of horrors. MSNBC.com. Retrieved from www.msnbc.msn.com/id/16909438/

New Schools for New Orleans [NSNO]. (n.d.). Transformations [Informational folder]. New Orleans: Author.

New Schools for New Orleans [NSNO]. (2007, August). New Orleans parents' guide to public schools. New Orleans: Author.

New Schools for New Orleans [NSNO]. (2008a). Lead. Retrieved from http://newschools forneworleans.org/

New Schools for New Orleans [NSNO]. (2008b). Serve. Retrieved from http://newschools forneworleans.org/

New Schools for New Orleans [NSNO]. (2008c). Start. Retrieved from http://newschools forneworleans.org/

New Schools for New Orleans [NSNO]. (2010a). Charter board member qualifications. Retrieved from http://newschoolsforneworleans.org/ 
New Schools for New Orleans [NSNO]. (2010b). Our impact. Retrieved from http://newschoolsforneworleans.org/

New Teacher Project [TNTP]. (2007, December 3). The New Teacher Project wins Fast Company magazine and Monitor Group's social capitalist award. Retrieved from www.tntp.org/ newsandpress/120307_TNTP.html

New Teacher Project [TNTP]. (2010). About us: Our business model. Retrieved from www .tntp.org

Omi, M., \& Winant, H. (1994). Racial formation in the United States: From the 1960s to the 1990s. New York: Routledge.

Parent, W. (2004). Inside the carnival: Unmasking Louisiana politics. Baton Rouge: Louisiana State University Press.

Randels, J. (2010). Passing on a torch. In K. L. Buras, J. Randels, K. Y. Salaam, \& Students at the Center, Pedagogy, policy, and the privatized city: Stories of dispossession and defiance from New Orleans (pp. 101-103). New York: Teachers College Press.

Recovery School District [RSD]. (2007, June 13). Two companies awarded the contract to develop master facility plan for Orleans Parish public schools [Press release]. Baton Rouge: Author.

Recovery School District [RSD] \& New Orleans Public Schools [NOPS]. (2008a, August). School facilities master plan for Orleans Parish. New Orleans: Authors.

Recovery School District [RSD] \& New Orleans Public Schools [NOPS]. (2008b, November 6). Superintendents' amendments: Recommendations to the Louisiana Board of Elementary and Secondary Education. New Orleans: Authors.

Ritea, S. (2006, August 12). Public schools compete for kids. Times-Picayune. Retrieved from www.nola.com

Saltman, K. J. (Ed.). (2007). Schooling and the politics of disaster. New York: Routledge.

Saltman, K. J. (2010, June). Urban school decentralization and the growth of "portfolio districts" [Policy brief]. East Lansing, MI: Great Lakes Center for Education Research and Practice. Retrieved from http://greatlakescenter.org/docs/Policy_Briefs/Saltman_ PortfolioDistricts.pdf

Save Our Schools-New Orleans, Louisiana [SOSNOLA]. (2008). Extend school facilities master plan public review period [Petition]. Retrieved from www.thepetitionsite .com/1/SOSNOLA-ExtendReviewPeriod

Scott, J. (2009). The politics of venture philanthropy in charter school policy and advocacy. Educational Policy, 23(1), 106-136.

Tate, W. F. (2008). "Geography of opportunity": Poverty, place, and educational outcomes. Educational Researcher, 37(7), 397-411.

Thevenot, B. (2009, May 17). Local school principals' pay reaches new heights. TimesPicayune. Retrieved from www.nola.com

Tisserand, M. (2007, August 23). The charter school flood. The Nation. Retrieved from http://www.thenation.com/article/charter-school-flood

United Teachers of New Orleans [UTNO], Louisiana Federation of Teachers [LFT], \& American Federation of Teachers [AFT]. (2006, November). "National model" or flawed approach? The post-Katrina New Orleans Public Schools. New Orleans: Author.

United Teachers of New Orleans [UTNO], Louisiana Federation of Teachers [LFT], \& American Federation of Teachers [AFT]. (2007a, June). No experience necessary: How the New Orleans school takeover experiment devalues experienced teachers. New Orleans: Author.

United Teachers of New Orleans [UTNO], Louisiana Federation of Teachers [LFT], \& American Federation of Teachers [AFT]. (2007b, October). Reading, writing, and reality check: An early assessment of student achievement in post-Katrina New Orleans. New Orleans: Author.

Weaver-Hightower, M. (2008). An ecology metaphor for educational policy analysis: A call to complexity. Educational Researcher, 37(3), 153-167. 


\section{State government}

Louisiana State Legislature: governor, senators, and representatives who pass and administer laws in Louisiana and mediate between government authorities at local and federal levels

\section{Louisiana Board and Elementary and Secondary} Education (BESE): state-level body that makes policy for public schools in Louisiana and governs Recovery School District

Recovery School District (RSD): state-governed school district, under authority of Louisiana state superintendent of education and BESE, that took over "failing" public schools in New Orleans
Documents (e.g., state constitution, education laws, Minimum Foundation Program, news articles)

Field notes; public hearing transcripts; documents (e.g., reports, news articles)

Public meeting observations; field notes; documents (e.g., school district data, quarterly reports, School Facilities Master Plan, news articles)

\section{Local government}

Bring New Orleans Back Commission (BNOB): commission established by mayor to formulate plans for city's reconstruction

\section{Orleans Parish School Board (OPSB) and New} Orleans Public Schools (NOPS): locally governed school district under authority of locally elected OPSB
Documents (e.g., online materials, committee reports)

Documents (e.g., online materials, school district data, reports, news articles)

\section{Nonstate actors}

\section{Cowen Institute for Public Education Initiatives:} action-oriented think tank at Tulane University

New Schools for New Orleans (NSNO): charter school incubator

teachNOLA-Teach For America-New Teacher

Project: alternative teacher recruitment triad affiliated with Recovery School District

New Leaders for New Schools (NLNS): school leader and charter school board member recruitment and training initiative

New Orleans Parent Organizing Network: parent organizing partner associated with above organizations
Interviews; field notes; documents (e.g., annual reports, surveys, white papers, newsletter)

Field notes; documents (e.g., organizational pamphlets, online materials, news articles, Parents' Guide to Public Schools) 
Louisiana Federation of Teachers (LFT): state affiliate of American Federation of Teachers

United Teachers of New Orleans (UTNO): local affiliate of American Federation of Teachers

Veteran teachers: native-born teachers who have taught in NOPS for $10-35$ years

Martin Luther King Elementary School: longstanding open-access public elementary school in Lower 9th Ward

\section{Lower 9 School Development Group (L9SDG):} community-based organization focused on School Facilities Master Plan and rebuilding of schools in Lower 9th Ward

\section{Save Our Schools-New Orleans, Louisiana} (SOSNOLA): grassroots parent organization focused on equity and school reform
Interview; documents (e.g., letters to state officials, legislative briefs, broadsides)

Group interviews; field notes; documents (e.g., policy briefs, reports)

Individual and group interviews

Oral histories; school-community event observations; field notes; documents (e.g., newsletters, school program materials); schoolneighborhood photos

Interviews; field notes; documents (e.g., demographic survey, architectural plans, call for Congressional investigation)

Interview; documents (e.g., petition, online materials)

Copyright $\odot$ Kristen L. Buras 
This article has been reprinted with permission of the Harvard Educational Review (ISSN 0017-8055) for personal use only. Posting on a public website or on a listserv is not allowed. Any other use, print or electronic, will require written permission from the Review. You may subscribe to HER at www.harvardeducationalreview.org. HER is published quarterly by the Harvard Education Publishing Group, 8 Story Street, Cambridge, MA 02138, tel. 617-4953432. Copyright (C) by the President and Fellows of Harvard College. All rights reserved. 